\title{
Lake Orta: the undermining of an ecosystem
}

\author{
Carla BONACINA \\ C.N.R. Istituto Italiano di Idrobiologia, L.go Tonolli 50, I 28922 Verbania Pallanza, Italy \\ e-mail: c.bonacina@iii.to.cnr.it
}

\begin{abstract}
From 1927 to 1986 Lake Orta (North-western Italy) received loadings coming from a rayon factory, rich in copper and ammonium sulphate. Immediately after the onset of pollution, the food web was destroyed: first phytoplankton, then zooplankton, and finally fish and ultraplankton disappeared from the lake. Twenty years later a rise in nitrate nitrogen and copper ions was recorded and in the early sixties ammonium nitrogen started to accumulate and $\mathrm{pH}$ to fall. In the meanwhile, a poorly structured biological community appeared, mainly composed of Cyclops abyssorum (copepod), Hexarthra fennica (rotifer) and Coccomyxa minor (green alga). Fish and benthonic animals were still absent. In 1986 the ammonium loading was substantially reduced (copper had been partially recovered since 1956), so that the in-lake ammonium concentration began to decrease. Some phyto-and zooplankton as well as benthic species were recorded in this period. Nevertheless, as $\mathrm{pH}$ was still very acid and alkaline reserve absent: a proposal to lime the lake was accepted and funded by regional authorities. Liming was performed in May 1989-June 1990 and resulted in a real improvement of the environment.
\end{abstract}

Key words: acidification, heavy metals, liming, lake recovery

\section{THE LAKE}

\subsection{Geo-morphological and hydrological characteristics}

Lake Orta (Fig. 1) is located in Northern Italy, northwest of Milan, and is the westernmost Italian glacial lake. It is the seventh largest Italian lake by volume and depth and occupies the south-western part of the larger Lake Maggiore drainage basin. Its outlet, the River Niguglia leaves the lake at its northern end (a unique feature in Italian subalpine lakes); it joins the River Strona, a tributary of the River Toce, which flows into Lake Maggiore.

Both Lake Orta and its drainage basin have a long, narrow shape extending in a N-S direction. The main sub-basins are located in the western part of the area, except for that of the River Pescone $\left(18 \mathrm{~km}^{2}\right)$, and are formed by the contributing areas of five streams: Bagnella, Acqualba, Pellino, Pellesina and Lagna (Fig. 1).

Some characteristics of Lake Orta are given in table 1. It is very important to note that the actual mean water residence time is 10.7 years. It has been calculated that after 10.7 years, $45 \%$ of the original water is still present in the lake (Bonacina \& Bonomi 1974).

The lake basin, formed by ice erosion on a pre-existing river valley, is mostly made up of gneiss, micashists and granites. Because of the geology of the catchment basin, the water of Lake Orta was originally poorly buffered, with total alkalinity ranging from 0.3 $0.4 \mathrm{meq}^{-1}$ (Monti 1929).

It was once classified as a warm monomictic lake, but it is now clear from intensive thermic studies performed in the last fifteen years that Lake Orta does not undergo a full circulation every year, and so must be considered an olo-oligomictic lake (Ambrosetti \& Barbanti 2001).

Lake Orta lies in a region of low human population density, with little agricultural development, so that pollution from domestic and agricultural sources is negligible. On the other hand, heavy industrial pollution originated from a rayon factory (Bemberg) located on its southern end and from many scattered plating industries on the south-western shores (Fig. 1).

\subsection{Chemical composition and the biological compartment in early twentieth century}

Our information about the natural chemical conditions of the lake is rather scanty: we know that $\mathrm{pH}$ ranged between 7.1 and 7.3 in the $50 \mathrm{~m}$ layer and between 6.9 and 7.1 at the depth of $100 \mathrm{~m}$ (Vollenweider 1963). In 1926 an alkalinity value of 0.3 meq $\mathrm{l}^{-1}$ was recorded (Baldi 1949). We may hypothesise, on the basis of drainage basin similarity, that there was a substantial similarity in the ionic balance between Lake Orta and the nearby Lake Mergozzo (Tab. 2).

We know that the lake had a high algal species richness (about 150 species) especially desmids and diatoms (Parona 1880; Giaj-Levra 1925).

The zooplankton population (Pavesi 1879; Monti 1930) was composed by seven species of cladocerans (four of which were Daphnia spp.) and five species of copepods, and they must have been very abundant, if Pavesi could write about them: "...extraordinarily abundant, so that the bottom of the net was filled with the usual gelatinous matter formed by the entomostracans" (Pavesi 1879). Rotifers were also abundant (Monti 1930). 


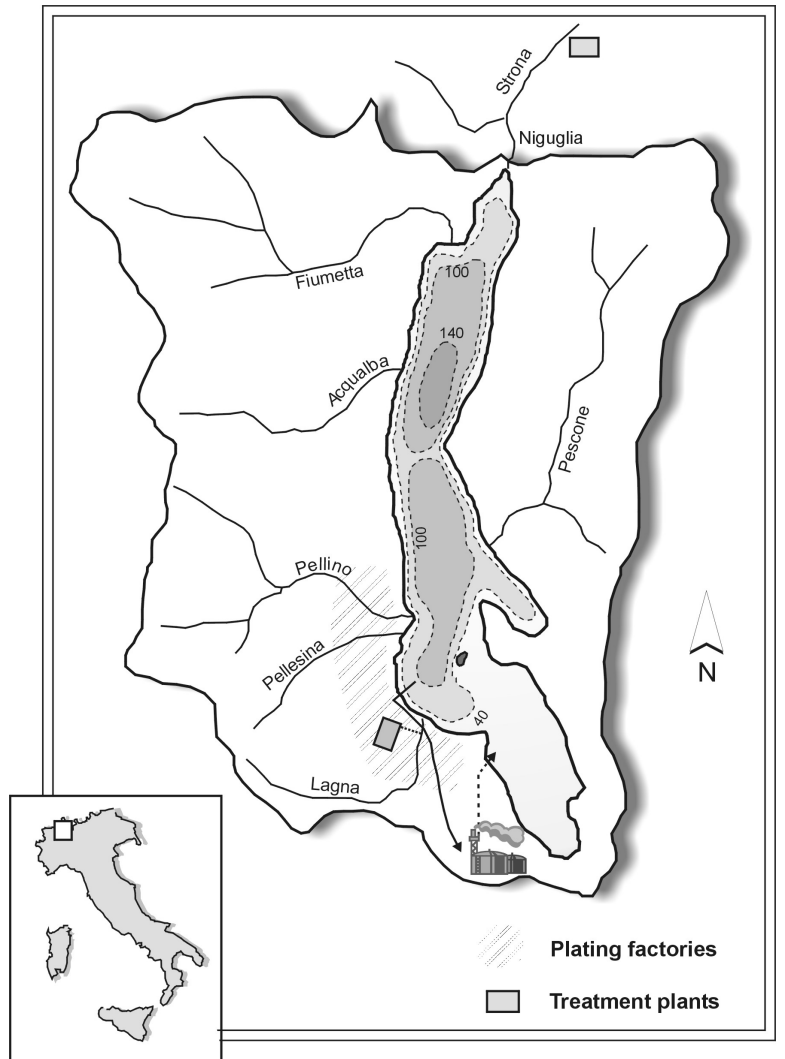

Fig. 1. Map of the lake and its drainage basin. Dotted arrow: Bemberg discharge; full arrow: Bemberg water intake.

As for fish (Tab. 3), we know (De Agostini 1927) that arctic char (Salvelinus alpinus), introduced in 19141916, was the most important commercial fish though other species were present in high densities, among others eel (Anguilla anguilla), pike (Esox lucius), shad (Alosa ficta lacustris), tench (Tinca tinca), perch (Perca fluviatilis), barbel (Barbus barbus), burbot (Lota lota), chub (Leuciscus cephalus). After 1901 Coregonus wartmanni (white fish) was introduced in the lake. In any case, commercial fishery was the most important economic activity for the inhabitants of the small towns surrounding the lake (De Agostini 1927).

Unluckily, nothing is known about the original bottom fauna, but sub-fossil records informed us of the presence of Spirosperma ferox (Oligochaeta: Tubificidae) (Bonacina et al. 1986b).

\section{A HISTORY OF POLLUTION (1926-1988)}

Lake Orta was heavily polluted by the effluents discharged since November 1926 from a rayon factory located at its southern end (Fig. 1), which used (and still uses) large quantities $\left(12,000 \mathrm{~m}^{3} \mathrm{~d}^{-1}\right.$, that is about $3 \%$ of mean outflow discharge) of its pure, soft water for industrial processes and, during a period of about fifty years,
Tab. 1. Some hydrographical and limnological features of Lake Orta.

\begin{tabular}{lc}
\hline Drainage basin area & $116 \mathrm{~km}^{2}$ \\
Mean altitude of drainage basin & $650 \mathrm{~m} \mathrm{a} . \mathrm{s} .1$. \\
Mean lake level altitude & $290 \mathrm{~m} \mathrm{a} \mathrm{s} 1$. \\
Lake area & $18.136 \mathrm{~km}^{2}$ \\
Lake volume & $1,286 \times 10^{6} \mathrm{~m}^{3}$ \\
Mean depth & $70.9 \mathrm{~m}$ \\
Maximum depth & $143 \mathrm{~m}$ \\
Water inflow (precipitation) & $1,901 \mathrm{~mm} \times \mathrm{y}^{-1}$ \\
Mean outflow discharge & $4.81 \mathrm{~m} 3 \mathrm{~s}^{-1}$ \\
Yearly outflow discharge & $151.688 \times 10^{6} \mathrm{~m}^{3}$ \\
Theoretical retention time & $8.478 \mathrm{y}^{-1}$ \\
Theoretical renewal rate & $0.118 \mathrm{y}^{-1}$ \\
Actual renewal rate & $0.093 \mathrm{y}^{-1}$ \\
Mean actual water residence time & $10.7 \mathrm{y}$ \\
\hline
\end{tabular}

Tab. 2. Ionic balance of Lake Mergozzo at full circulation time.

\begin{tabular}{lcc}
\hline & meq $1^{-1}$ & $\%$ \\
\hline $\mathrm{Ca}^{++}$ & 0.280 & 26.9 \\
$\mathrm{Mg}^{++}$ & 0.120 & 11.5 \\
$\mathrm{Na}^{+}$ & 0.090 & 8.7 \\
$\mathrm{~K}^{+}$ & 0.030 & 2.9 \\
$\mathrm{NH}_{4}^{+}$ & 0.00 & 0.0 \\
$\mathrm{H}^{+}$ & 0.00 & 0.0 \\
$\sum$ cations & $\mathbf{0 . 5 2 0}$ & $\mathbf{5 0 . 0}$ \\
$\mathrm{HCO}_{3}^{-}$ & 0.200 & 19.2 \\
$\mathrm{SO}^{-}$ & 0.230 & 22.1 \\
$\mathrm{Cl}^{-}$ & 0.060 & 5.8 \\
$\mathrm{NO}_{3}{ }^{-}$ & 0.030 & 2.9 \\
$\sum$ anions & $\mathbf{0 . 5 2 0}$ & $\mathbf{5 0 . 0}$ \\
\hline
\end{tabular}

discharged into the lake increasing amounts of copper and ammonium sulphate from the manufacture of cellulose and iron salts from a partial copper recovering process. In 1927, water samples from the open lake were devoid of phyto- and zooplankton (Bachmann, in litteris, from Baldi 1949); by 1929 fish had practically disappeared and the lake waters were defined as "sterile" (Monti 1930).

The reason for this unusual series of events was, as demonstrated by Monti (1930), the algicidal effect of the copper salts, which killed all of the phytoplankton, destroying the first level of the food web. Logically enough, the disappearance of phytoplankton was followed by that of zooplankton; as for the fish, injured by the purely mechanical action of the ferric and cupric ions coating their gills and with no food to eat, they inevitably died, though more slowly than algae and microcrustaceans (Monti 1930). Moreover, that Lake Orta waters were toxic for salmonids was demonstrated by Calamari \& Marchetti (1975).

The factory which caused this ecological disaster tried in many ways to deny its responsibility. The inhabitants were divided between fishermen deprived of their livelihood and the people who had found work in 
Tab. 3. Spatial and trophic relationship of the "original" fish population in Lake Orta. (from Bonacina \& Bonomi 1984).

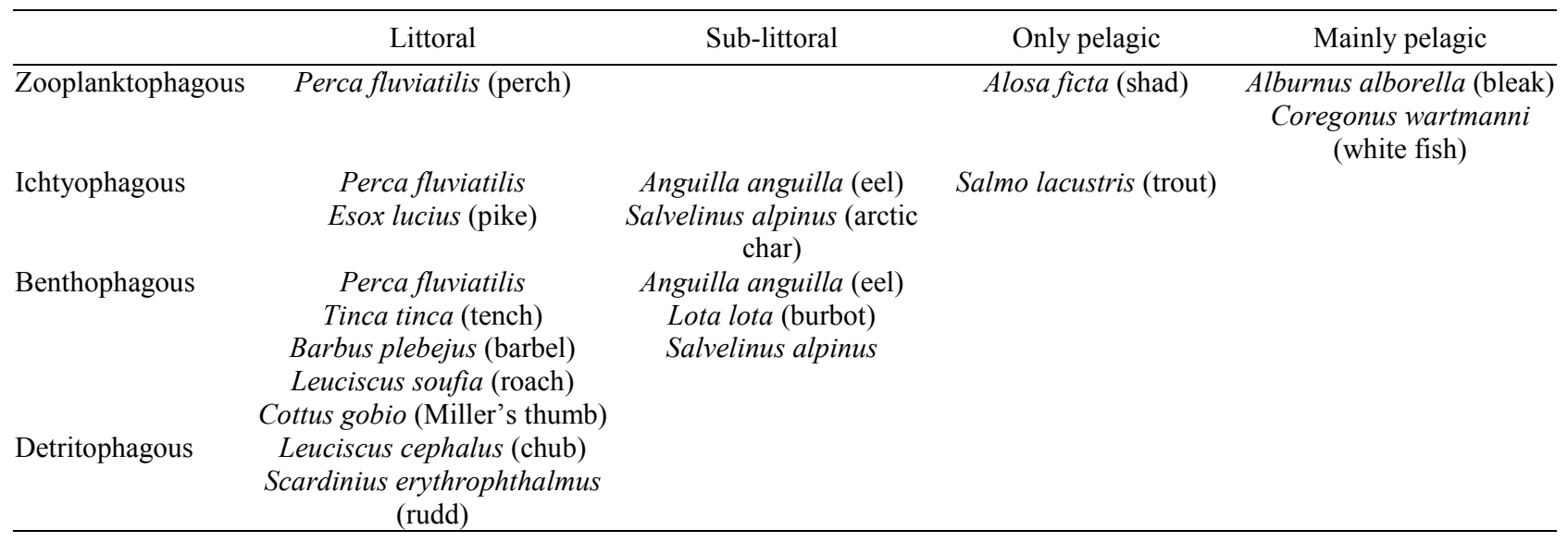

the factory. Eventually, all fishermen were employed by the factory and the controversy stopped. But the problem of the lake remained.

The factory itself supplied the information in the following table (Tab. 4, from Bonacina \& Bonomi 1984), in which yearly loadings are reported:

Tab. 4. Bemberg loadings. Note that the decrease in 19751979 was due to a crisis in the sector of technological fibres and not to a recovering action.

\begin{tabular}{lcc}
\hline & TIN $\left(\mathrm{t} \mathrm{y}^{-1}\right)$ & $\mathrm{Cu}\left(\mathrm{t} \mathrm{y}^{-1}\right)$ \\
\hline $1947-1958$ & $1000-2000$ & $40-80$ \\
$1959-1967$ & (regularly increasing) & \\
$1968-1974$ & 2000-3000 & $4-5$ \\
$1975-1979$ & $\cong 3000(\max 3350$ in 1970$)$ & $\cong 4$ \\
\hline
\end{tabular}

It was only too easy to foresee that the huge amounts of ammonium sulphate discharged into the lake water would cause an increase in nitric nitrogen deriving from ammonium oxidation, a progressive acidification caused by the nitrification, a strong decrease of dissolved oxygen and, eventually, the destruction of the alkaline reserve of the lake which was in itself poorly buffered because of the igneous nature of its drainage basin.

A number of investigations carried on through the years enable us to follow, step by step, the evolution of the chemical and biological features of the lake. The first systematic study planned on a yearly basis was that of Baldi (1949) from which we can deduce, for the year 1947, a mean ammonium concentration of about 0.4-0.5 $\mathrm{mg} \mathrm{N}-\mathrm{NH}_{4} \mathrm{l}^{-1}$, a mean nitrate concentration of 1.2-1.5 $\mathrm{mg} \mathrm{N}-\mathrm{NO}_{3} \mathrm{l}^{-1}$ and $\mathrm{pH}$ values ranging from 6.3 to 8.1 with prevailing acid values $(23.1 \%$ of the data refer to a value of 6.4). In the same paper, Baldi stated that "plankton population in Lake Orta is almost always absent".

In 1952-1953, Moretti (1954a; 1954b) conducted an extensive study on the littoral fauna. He sampled 28 stations all around the lakeshores and concluded "all the littoral fauna of the lake is reduced to a tiny, monotonous community composed of highly adaptable species". He found only 11 trichopteran species; turbellarian, chironomids, odonata and coleoptera were present at some station with very low numbers. Numerous individuals of Tubifex sp. were collected only at Station 10, corresponding to the harbour of the town of Orta, an environment highly polluted by urban wastes. The author also reports the sporadic presence of Cyclops serrulatus and $C$. albidus in some widespread sampling points, of sponge colonies at station 24 , located on the western shore of the lake, corresponding to an uninhabited zone, and of schools of bleak fry (Alburnus alburnus alborella) at the mouth of the River Qualba.

In 1956 (Corbella et al. 1958) a mean annual concentration of $3.3 \mathrm{mg} \mathrm{N}-\mathrm{NO}_{3} \mathrm{l}^{-1}$ was calculated, with an increase of nearly $2 \mathrm{mg}$ over the 1947 values; values for $\mathrm{N}-\mathrm{NH}_{4}$ can be considered unchanged. At the same time, $48 \%$ of $\mathrm{pH}$ values were lower than 6.4 and a considerable hypolimnetic oxygen deficit (a major feature of the lake in the subsequent years) began to be evident. The authors also stated that zooplankton was completely absent; on the other hand, they found an abundant population of the blue-greens Aphanothece clathrata, Chroococcus minimus, Oscillatoria limnetica (at that time classified as Lyngbya limnetica), Microcystis aeruginosa, together with Golenkinia radiata and some species of diatoms.

From 1958 on, the copper was almost completely recovered from the rayon factory effluent (a mean yearly load of $3.8 \mathrm{t} \mathrm{Cu}$ was calculated for the period 19581979, against a value of $60 \mathrm{t} \mathrm{Cu}$ for the previous period 1947-1957), but a new source of copper and other heavy metals emerged in the same period, constituted by many small plating factories located in the south western part of the drainage basin, see figure 1 (an estimated mean load of $13 \mathrm{t} \mathrm{Cu} \mathrm{y}^{-1}$, Bonacina et al. 1973).

From October 1959 to September 1961 (Vollenweider 1963), mean concentrations of $1.1 \mathrm{mg} \mathrm{N}^{-N_{4}} \mathrm{l}^{-1}$ and $4.1 \mathrm{mg} \mathrm{N}-\mathrm{NO}_{3} \mathrm{l}^{-1}$ were observed. In the same period, the author pointed out a tendency towards heavier acidifi- 
cation $(20 \%$ of measured values ranged between 4.0 and $4.2 \mathrm{pH}$ units) and a greater oxygen depletion (hypolimnetic oxygen consumption was calculated as $4200 \mathrm{t} \mathrm{y}^{-1}$ for 1960 and $3700 \mathrm{t} \mathrm{y}^{-1}$ for 1961). A mean $\mathrm{Cu}$ concentration of $85 \mu \mathrm{g} \mathrm{l}^{-1}$ was also measured. Vollenweider was the first to recognize that ammonia in-lake oxidation was the pivot of Lake Orta chemistry: it caused $\mathrm{pH}$ to decrease, nitrate to accumulate and, as a consequence of the low $\mathrm{pH}$, it permitted ionic copper to remain dissolved in the water. In the same period, O. limnetica was again the dominant phytoplankton species, while zooplankton was represented mainly by the rotifer $\mathrm{Bra}$ chionus calyciflorus and the cyclopoid copepod Cyclops "strenuus".

In 1968 (Ruggiu 1969) a microbenthonic profundal fauna (mainly protozoa and rotifers) was discovered. It was characterised by little diversity and high density.

In 1968-1969 (Bonacina 1970) mean $\mathrm{N}^{-\mathrm{NH}_{4}}$ concentration increased to $4 \mathrm{mg} \mathrm{l}^{-1}$. In the same period, mean $\mathrm{N}_{-} \mathrm{NO}_{3}$ concentration reached a value of $5 \mathrm{mg} \mathrm{l} \mathrm{l}^{-1}$. This means that the nitrification rate was limited, probably by low $\mathrm{pH}$; reduced nitrification had the effect of slightly increasing $\mathrm{pH}$ values, the most represented class of which ranged between 4.6 and 4.8. Hypolimnetic oxygen consumption was calculated as $5700 \mathrm{t} \mathrm{y}^{-1}$. As for the biological compartment, the author confirmed the presence of $O$. limnetica and $C$. "strenuus", pointing out in the meanwhile the appearance of Coccomyxa (now Choricystis) minor var. gallica (green). Sediment samples collected occasionally confirmed the complete absence of profundal macrobenthonic fauna.

Again in 1968-1969, a research was performed on the littoral fauna (Oioli 1969). Seasonal samples were collected in four littoral stations and the presence of chironomidae, oligochaeta, tipulidae, trichopterans, amphipoda and nematodes was pointed out. This was a considerable enrichment, compared with what had been found by Moretti (1954a; 1954b).

In 1971 (Barbanti et al. 1972) the mean concentration of $\mathrm{N}-\mathrm{NH}_{4}$ reached $4.8 \mathrm{mg} \mathrm{l}^{-1}$, that of $\mathrm{N}-\mathrm{NO}_{3} 5.5 \mathrm{mg}$ $1^{-1}$, mean $\mathrm{pH}$ value was 4.5 , mean oxygen saturation $60 \%$. The biological community was unchanged from that existing in 1968-1969.

Sporadic analyses conducted in the years 1972-1979 confirmed the above situation.

In 1976 a new water pollution law regulating the discharge of industrial wastes into a lake was passed by the Italian Parliament. It allowed a maximum concentration of $15 \mathrm{mg} \mathrm{N}^{-N_{4}} \mathrm{l}^{-1}$ and $0.1 \mathrm{mg} \mathrm{Cu} \mathrm{l}^{-1}$, that is for a flow of 12,000 cubic meters a day, $65.7 \mathrm{t} \mathrm{N}^{-\mathrm{NH}_{4} \mathrm{y}^{-1}}$ and $0.4 \mathrm{t} \mathrm{Cu} \mathrm{y}^{-1}$. So the factory which was the major source of industrial pollution began to build a huge treatment plant which would almost completely recover the copper and ammonium loadings. It came into operation in 1980, and in a period of two years the annual NNH4 loading was reduced from 3,350 t (maximum loading of 1970, Tab. 4) to about $30 \mathrm{t}$ and the annual $\mathrm{Cu}$ loading from 4 to $0.2 \mathrm{t}$ (Tab. 5). In the meanwhile, two treatment plants were built to collect domestic wastes (Fig. 1). The one built on the River Lagna was subsequently adapted so as to be able also to treat industrial wastes from plating industries. The lake reacted quickly to these variations (Bonacina et al. 1986a; Mosello et al. 1986a, 1986b; Bonacina et al. 1988a, 1988b): from February 1981 to February 1988 the mean concentration of $\mathrm{N}-\mathrm{NH}_{4}$ decreased from 4.6 to $1.4 \mathrm{mg} \mathrm{l}^{-1}$, that of $\mathrm{N}-\mathrm{NO}_{3}$ from 4.46 to $3.80 \mathrm{mg} \mathrm{l}^{-1}$ (values measured during each circulation periods); nevertheless, the lake waters remained very acid (maximum $\mathrm{pH}$ value at the overturn 4.4 in 1987, minimum value 3.9 in 1985), the copper content did not show any significant decrease and nitrification processes were very slow because of the low $\mathrm{pH}$ (Calderoni et al. 1990).

Tab. 5. Bemberg loadings (from Bonacina \& Bonomi 1984).

\begin{tabular}{lcc}
\hline & TIN $\left(\mathrm{t} \mathrm{y}^{-1}\right)$ & $\mathrm{Cu}\left(\mathrm{t} \mathrm{y}^{-1}\right)$ \\
\hline 1980 & 1450 & 0.8 \\
1981 & 919 & 0.8 \\
1982 & 34 & 0.3 \\
1983 & 27 & 0.2 \\
\hline
\end{tabular}

It might be appropriate at this point to give some information, supplied by the factory itself, about the main characteristics of the Bemberg effluent (Tab. 6).

Tab. 6. Physical features of the Bemberg effluent.

\begin{tabular}{lccc}
\hline period & $\mathrm{pH}$ & temperature & discharge \\
\hline $1959-1974$ & 9.5 & $22^{\circ} \mathrm{C}$ & $12,000 \mathrm{~m}^{3} \mathrm{~d}^{-1}$ \\
$1975-1983$ & 6.5 & $20^{\circ} \mathrm{C}$ & $12,000 \mathrm{~m}^{3} \mathrm{~d}^{-1}$ \\
\hline
\end{tabular}

The coming into operation of the treatment plant, with the consequent great abatement of ammonium and copper loadings, was a fundamental turning point in the biological history of Lake Orta.

As regards phytoplankton, already in 1981 the two dominant species $(O$. limnetica and $C$. minor) were joined by Microcystis aeruginosa (blue-green), which disappeared in the following years, Scenedesmus armatus (green) and Achnanthes minutissima (diatom) (Bonacina et al. 1988a). The studies conducted in the following years revealed wide and continuous modifications in the composition of the phytoplankton, A wide-ranging research carried out in 1985, which included primary production measurements, gave us a detailed picture of the phytoplankton population and its photosynthetic activity before liming (Pizzolon et al. 1992). The most important feature issuing from this work is that, for the first time, the phytoplankton community showed an organisation and seasonal successions comparable to those prevailing in the deep lakes of the temperate zone. The main difference consisted in its specific composition, which was clearly still dependent on the peculiar chemi- 
stry of the lake; from this point of view, the lasting absence of diatoms (replaced by green algae), the persistence of $C$. minor as the most important species, the decrease of blue-green algae compared with previous years and the high density of ultraplankton were very meaningful (Ruggiu et al. 1992).

During the following years, regular observations confirmed the variability and lack of stability of the phytoplankton community. At the end of 1988, bluegreen algae had practically disappeared and the once dominant Coccomyxa minor had undergone a marked decrease (Ruggiu \& Morabito 1990). Diatoms were still lacking and the whole community was characterised by chlorophyceans (Ruggiu et al. 1992).

Zooplankton also reacted quickly to the reduced amount of dissolved ammonia, showing a tendency towards an increasing complexity of community structure: from 1980 on, the three species which represented the unique zooplanktonic populations, that is Cyclops abyssorum (Crustacea, Copepoda), formerly called $C$. "strenuus", Brachionus calyciflorus and Hexarthra fennica (Rotifera, Monogononta), were joined by Asplanchna brightwelli (Rotifera) in 1981, B. urceolaris (Rotifera) and Bosmina longirostris (Cladocera) in 1984, Daphnia obtusa and Chydorus sphaericus (Cladocera) in 1986 (Bonacina et al. 1987a), D. longispina (Cladocera), Keratella cochlearis, K. quadrata, Lecane luna and Anuraeopsis fissa (Rotifera) in 1987 (Bonacina, unpublished), Alona rectangula (Cladocera) in 1989 (Bonacina, unpublished). The zooplankton population is thus assuming a complex structure characterised by the contemporary presence of micro- and macro-filtrators and predators.

Profundal benthic populations were absent in Lake Orta from the very beginning of the pollution, as demonstrated by the study of sediment cores taken in various parts of the bottom (Bonacina et al. 1986b). Only a small protozoan population settled in the profundal sediments at some time between 1956 (Corbella et al. 1958) and 1968 (Ruggiu 1969). However, in 1983 the bottom of the whole lake from 20 to $140 \mathrm{~m}$ depth was colonised by an abundant population of the tubificid Tubifex tubifex, a species very common in freshwater environments but absent in the profundal of Lake Orta since 1926. A detailed study on the seasonal variations and biology of this population was completed in 1984 (Bonacina et al. 1987b): T. tubifex abundance underwent wide numerical changes, mainly in the compartment of immature individuals; the population increased from January to June, declined dramatically in July, reached its maximum density in late summer and decreased again in November. The clutch size (eggs or embryos/cocoon) of this particular T. tubifex living in Lake Orta was larger than in previously studied populations from other lakes and the mortality of mature and ovigerous individuals appeared to be very low.
In 1987-1988 anglers gave the first indication of the appearance of a perch (Perca fluviatilis ) population. An extensive study of fish community started in 1989 (Giussani 1990) and allowed to ascertain that it was composed mainly (90-95\%) by perch, the other species present being chub (Leuciscus cephalus ) and pumpkinseed (Lepomis gibbosus ). Owing to the biological situation of the lake, in particular to the absence of bleak (Alburnus alburnus alborella), rudd (Scardinius erytrophthalmus) and other coarse fish, perch in Lake Orta grows very well in the first three years, while as the species becomes piscivorous, the growth slows down (Monti \& Giussani, pers. comm.).

\section{3. "A MODEST PROPOSAL"}

The situation had come to a stalemate, as showed above: the loadings had substantially decreased, as had ammonia concentration in lake, but $\mathrm{pH}$ was still very low and consequently copper content too high. The decrease in ammonia concentration was mainly due to the outflow of "old" water rich in ammonium, but this is only one of two mechanisms on which is based the removal of ammonium nitrogen from the lake. The second one is due to the biochemical oxidation of ammonium to nitrates and it is strictly connected with the $\mathrm{pH}$ : in fact it starts at $\mathrm{pH}$ as low as 4.6-4.8 and stops at $\mathrm{pH}$ lower than 3.9. Nitrification is a reaction that produces hydrogen ions and, as a result, environmental acidification. Therefore, as the reaction goes on, it tends to produce the conditions which stop the nitrification itself. Later on, in Lake Orta $\mathrm{pH}$ gradually increased because of the alkalinity carried from the drainage basin by the inflow waters, once more reaching values consistent with the nitrification. It was evident, at that point, that only the reestablishment of an adequate alkaline reserve would permit the complete oxidation of residual $\mathrm{N}-\mathrm{NH}_{4}$ and the maintenance of nearly neutral $\mathrm{pH}$ values.

It was in 1984 (Bonacina \& Bonomi 1984) that the idea of "liming" Lake Orta was first put forward. Liming is a well-known operation widely applied in Scandinavian and Canadian lakes acidified by acid rains (Lessmark \& Thörnelöf 1986). However, in those areas it has to be repeated every year, because of the continuous inflow of acidity, whereas in Lake Orta once would have been enough. As a consequence, 1984 saw the start of a research program aimed at evaluating the chemical budget of the lake, taking into account the input from the tributaries, atmospheric deposition on the lake surface, the effluent from the rayon factory and the output through the outlet (Mosello et al. 1986a, 1986b; Mosello et al. 1991). The results, taken together with the variation in the chemistry of the lake waters, made it possible to calibrate an input-output model which considered the effect of the input of alkalinity from the watershed on the acidity of the lake. The model gave 15-20 years as the time necessary for the lake to reach a total alkalinity of between 100 and $200 \mu \mathrm{eq} \mathrm{l}^{-1}$ (Bonacina et 
al. 1987a, 1988b; Mosello et al. 1991; Mosello \& Calderoni 1990).

For this reasons, the CNR-Istituto Italiano di Idrobiologia proposed (Bonacina et al. 1988b, Calderoni et al. 1990) a "Plan for a direct recovery intervention" which consisted in neutralising the lake waters through the addition of carbonate (liming). The proposal was approved by the Provincial and Regional Administrations and sponsored by the Ministry of the Environment.

The project involved spreading on the lake surface a slurry of lime, in amount equivalent to a total of 18,000 tons of pure $\mathrm{CaCO}_{3}$, using finely powdered natural limestone (dolomite). On the basis of the model used, the resulting alkalinity was predicted to be about $50 \mu \mathrm{eq} \mathrm{l}^{-1}$, even after the complete oxidation of the ammonium. Funding was available only for a part of the project, for an addition of pure calcium carbonate of 10,700 tons. This amount was added to the lake from May 1989 until June 1990.

The calcium carbonate used for the liming was natural limestone, containing $20 \%$ of water; the dry part was composed of $92 \% \mathrm{CaCO}_{3}, 6 \% \mathrm{MgCO}_{3}$ and $2 \%$ impurity, mainly silica. The trace metal content was $7,1,2.7$, $0.01 \mathrm{ppm}$ for $\mathrm{Cr}, \mathrm{Cu}, \mathrm{Ni}$ and $\mathrm{Hg}$, respectively (Mosello et al. 1991).

The spreading was done from a boat equipped with tank (about 80 tons), concrete mixer $\left(9 \mathrm{~m}^{3}\right)$, mixing tank $\left(10 \mathrm{~m}^{3}\right)$, and jet pump for the spreading of the slurry. The daily spraying capacity was about 90 tons of pure calcium carbonate. The slurry, made with lake water, contained about $35 \%$ of lime. The calcium carbonate was added to the lake to the amount of 400-450 tons per week, with interruptions in August, September and December-January, due to funding and technical problems. The operation was begun in the southern part of the lake, i.e. the portion of the lake farthest from the outflow (Fig. 1). Initially, the calcium carbonate was sprayed on to the lake surface, but in this way it remained mainly in the upper water layers, spreading over the epilimnion of the whole lake. For this reason, in July 1989 it was decided to change the technique used to add the calcium carbonate: from then on, it was pumped through a pipe from the boat to a depth of about $13 \mathrm{~m}$, so as to overpass the metalimnion. Work was suspended for a period during the winter, because the slurry froze in the pipes and tanks; when the operation was resumed, in the period March-June 1990, the spreading was done once again on the lake surface.

The lake reacted very quickly to the liming. The results of the operation on the lake itself and on the biological community are the object of this volume.

\section{REFERENCES}

Ambrosetti, W. \& L. Barbanti. 2001. Temperature, heat content, mixing and stability in Lake Orta: a pluriennal investigation. J. Limnol., 60(1): 60-68.

Baldi, E. 1949. Il Lago d'Orta, suo declino biologico e condizioni attuali. Mem. Ist. ital. Idrobiol., 5: 145-188.
Barbanti, L., C. Bonacina, G. Bonomi \& D. Ruggiu. 1972. Lago d'Orta: situazione attuale e previsioni sulla sua evoluzione in base ad alcune ipotesi di intervento. Ed. Istituto Italiano di Idrobiologia, Pallanza: $113 \mathrm{pp}$.

Bonacina, C. 1970. Il Lago d'Orta: ulteriore evoluzione della situazione chimica e della struttura della biocenosi lacustre. Mem. Ist. ital. Idrobiol., 26: 141-204.

Bonacina, C., W. Ambrosetti, L. Barbanti, G. Bonomi, A. Calderoni, R. Mosello, D. Ruggiu, A. Ferrari, V. Libera, P. Panzani Guida, B. Sulis, A. Pranzo \& G. Tartari. 1986a. L'evoluzione pluriennale delle caratteristiche chimiche e delle strutture biotiche del Lago d'Orta, come conseguenza degli interventi di risanamento. Documenta Ist. ital. Idrobiol., 17: 64-76.

Bonacina, C. \& G. Bonomi. 1974. La conoscenza dell'origine ed evoluzione dell'inquinamento del Lago d'Orta come base per la formulazione di strumenti previsionali indispensabili ad una politica di intervento. Atti $I^{\circ}$ Convegno Internazionale sull'Ambiente e sulla Crisi dell'Energia, Torino, 8-12 Maggio 1974, IV: 25 pp.

Bonacina C. \& G. Bonomi. 1984. I grandiosi effetti ambientali determinati dalle prime fasi del disinquinamento del Lago d'Orta. Documenta Ist. ital. Idrobiol., 2: 24 pp.

Bonacina, C., G. Bonomi, L. Barbanti, R. Mosello \& D. Ruggiu. 1988a. Recovery of an industrially acidified, ammonium and heavy metals polluted lake (Lake Orta, N. Italy), due to the adoption of treatment plants. Verh. int Ver. Limnol., 23: 535-544.

Bonacina, C., G. Bonomi, L. Barbanti, R. Mosello D. Ruggiu \& G. Tartari. 1988b. Lake Orta (N. Italy): recovery after the adoption of restoration plans. In: N.W. Schmidtke (Ed.), Toxic Contamination in Large Lakes. Vol. $2^{\circ}$ : Impact of Toxic Contaminants on Fisheries Management. Proc. "World Conference on Large Lakes", Mackinac Island, Mich., May 18-21, 1986: 101-130.

Bonacina, C., G. Bonomi, A. Calderoni \& R. Mosello. 1987a. Evoluzione recente dell'inquinamento del Lago d'Orta e proposta di un intervento per il suo recupero. Documenta Ist. ital. Idrobiol., 14: 197-213.

Bonacina, C., G. Bonomi \& C. Monti. 1986b. Oligochaete cocoon remains as evidence of past lake pollution. Hydrobiologia, 143: 395-400.

Bonacina, C. G. Bonomi \& C. Monti. 1987b. Population dynamics of Tubifex tubifex, first settler in the profundal of a copper and ammonia polluted, recovering lake (Lake Orta, North Italy). Hydrobiologia, 155: 305.

Bonacina, C., G. Bonomi \& D. Ruggiu. 1973. Reduction of the industrial pollution of Lake Orta (N. Italy): an attempt to evaluate its consequences. Mem. Ist. ital. Idrobiol., 30: 149-168.

Calamari, D. \& R. Marchetti. 1975. Predicted and observed acute toxicity of copper and ammonia to rainbow trout (Salmo gairdneri Rich.). Progr. Wat. Technol., 7: 569577.

Calderoni, A., R. de Bernardi \& R. Mosello. 1990. Proposta di risanamento del Lago d'Orta tramite liming. In: Bonacina, C., A. Calderoni \& R. de Bernardi (Eds), Ricerche limnologiche sul Lago d'Orta finalizzate al suo risanamento. Documenta Ist. ital. Idrobiol., 28: 117-131.

Corbella, C., V. \& L. Tonolli. 1958. I sedimenti del Lago d'Orta testimoni di una disastrosa polluzione cupro-ammoniacale. Mem. Ist. ital. Idrobiol., 10: 9-50.

De Agostini, G. 1927. Flora, fauna e pesca del Lago d'Orta. Cusiana, 6(11): 121-124.

Giaj-Levra, P. 1925. Diatomee del Lago d'Orta. Atti Soc. Ligustica Sc. Lett., 5: 66-82.

Giussani, G. 1990. La fauna ittica del Lago d'Orta. In: Bonacina, C., A. Calderoni \& R. de Bernardi (Eds), Ricerche limnologiche sul Lago d'Orta finalizzate al suo risanamento. Documenta Ist. ital. Idrobiol., 28: 109-115. 
Lessmark, O. \& E. Thörnelöf. 1986. Liming in Sweden. Water, Air and Soil Pollution, 31: 809-815.

Monti, R. 1929. Limnologia comparata dei laghi insubrici. Verh. int. Ver. Limnol., 4: 462-497.

Monti, R. 1930. La graduale estinzione della vita nel limnobio del Lago d'Orta. Rend. Ist. Lomb. Sc. Lett., 63: 3-22.

Moretti, G.P. 1954a. La distribuzione dei Tricotteri lungo il litorale del Lago d'Orta. Mem. Ist. ital. Idrobiol., 8: 257270.

Moretti, G.P. 1954b. Il limnobio neritico dei Tricotteri a testimonianza dell'attuale situazione biologica del Lago d'Orta. Boll. Soc. Eustachiana, 47: 59-117.

Mosello, R., R. Baudo \& G.A. Tartari. 1986a. Metal concentrations in a highly acidic lake: L. Orta, (Northern Italy). Mem. Ist. ital. Idrobiol., 44: 73-96.

Mosello, R., C. Bonacina, A. Carollo, V. Libera \& G.A. Tartari. $1986 \mathrm{~b}$. Acidification due to in- lake ammonia oxidation: an attempt to quantify the proton production in a highly polluted subalpine italian lake (Lake Orta). Mem. Ist. ital. Idrobiol., 44: 47-71.

Mosello, R. \& A. Calderoni. 1990. Previsioni sull'evoluzione idrochimica del Lago d'Orta. Atti VIII Congr. A.I.O.L. Pallanza, 1-3 giugno 1988: 521-531.

Mosello, R., A. Calderoni \& R. de Bernardi. 1991. Mass budget as a tool for predicting the response to liming of the acidified, ammonium polluted subalpine Italian lake (Lake Orta). Verh. int. Ver. Limnol., 24: 1044-1048.
Oioli, G.F. 1969. Ricerche sulla fauna litorale del Lago d'Orta. Tesi di Laurea, Fac. di Scienze, Univ. Milano, Anno Accademico 1968-1969: 140 pp.

Parona, C. 1880. Prime ricerche intorno ai protisti del Lago d'Orta, con cenno della loro corologia italiana. Boll. Scientifico, Pavia 2 (1): 17-26.

Pavesi, P. 1879. Ulteriori studi sulla fauna pelagica dei laghi italiani. Rend. R. Ist. Lomb. Sc. Lett., 12: 688-707.

Pizzolon, L., D. Ruggiu \& G. Morabito. 1992. Primary production and phytoplankton communities in the acidified Lake Orta (N. Italy) after the removal of ammonia pollution. Mem. Ist. ital. Idrobiol., 51: 29-52.

Ruggiu, D. 1969. Benthic Ciliates in the profundal of Lake Orta (Northern Italy). Verh. int. Ver. Limnol., 17: 255-258.

Ruggiu, D., A. Bachiorri, C. Bonacina, G. Bonomi, M. Manca, G. Marengo, P. Menozzi, G. Morabito, E. Moggian Barban, P. Panzani, V. Rossi \& A. Tondina. 1992. In: Calderoni, A. \& R. de Bernardi (Eds), Atti Conv.: Orta, un lago da salvare: le fasi del suo recupero. Orta, 9-10 Aprile 1990. Documenta Ist. ital. Idrobiol, 38: 107-111.

Ruggiu, D. \& G. Morabito. 1990. Studi sul fitoplancton effettuati negli anni 1987 e 1988, nel quadro dell'evoluzione a lungo termine del Lago d'Orta. In: Bonacina, C., A. Calderoni \& R. de Bernardi (Eds), Ricerche limnologiche sul Lago d'Orta finalizzate al suo risanamento. Documenta Ist. ital. Idrobiol., 28: 89-100.

Vollenweider, R.A. 1963. Studi sulla situazione attuale del regime chimico e biologico del Lago d'Orta. Mem. Ist. ital. Idrobiol., 16: 21-125. 